\title{
APPLICABILITY OF SHANSEP METHOD IN EVALUATION OF PRECONSOLIDATION PRESSURE
}

Scientific paper

(Received: 17 December 2019; accepted: 15 June 2020)

\author{
Chalabi Youssouf \\ Department of Civil Engineering, Faculty of Technology, AbouBekr Belkaid University, Tlemcen, Algeria, \\ PhD Student \\ Corresponding author: youcefchalabi333@yahoo.fr \\ Reiffsteck Philippe \\ Sols, Roches et Ouvrages géotechniques (SRO), Institut Français des Sciences et Technologies des \\ Transports, de l'Aménagement et des Réseaux (IFSTTAR), Marne la Vallée, France, PhD, Senior \\ Researcher

\section{Zadjaoui Abdeldjalil} \\ Department of Civil Engineering, Faculty of Technology, AbouBekr Belkaid University, Tlemcen, Algeria, \\ Full professor
}

\begin{abstract}
This article presents an experimental study on 81 specimens made from three different mixtures of clay and sand. To ensure uniform initial parameters, all specimens were prepared with an initial water content of $30 \%$. Two series of unconsolidated undrained shear tests under different overconsolidation ratios were conducted on a direct shear apparatus: the first aims to determine the SHANSEP (Stress History and Normalized Soil Engineering Properties) parameters namely $S$ and $m$, whereas the second is used for evaluating the preconsolidation pressure. This work has provided an opportunity to investigate the influence of sand content on SHANSEP parameters and moreover to study the reliability of the preconsolidation stress estimated by the SHANSEP procedure.
\end{abstract}

Keywords: Undrained shear strength; Overconsolidation ration; Preconsolidation pressure; SHANSEP method. 


\section{INTRODUCTION}

Preconsolidation pressure $\left(\sigma_{p}^{\prime}\right)$ is usually defined as the maximum pressure experienced by soil during its history [1-3]. This pressure is a major geotechnical parameter for analysis and prediction of settlement, overconsolidation ratio (OCR), stress history, and short term stability problems in soft clays [4-7]. Many empirical methods have been developed to interpret $\sigma_{p}^{\prime}$ of soft soils from standard oedometer tests $[1-3,8-10]$ and in situ test results using various correlations [11-13].

Several studies have attempted to establish relationships between undrained shear strength $\left(\mathrm{s}_{\mathrm{u}}\right)$ and preconsolidation pressure. For normally consolidated clays, Skempton [14] suggested a linear correlation between the normalized undrained shear strength determined from the field vane shear test $\left(\mathrm{s}_{\mathrm{u}}^{\mathrm{FV}}\right)$ and the plasticity index (PI). Thereafter, Chandler [15] extended the validity of the same correlation for overconsolidated clays. For Scandinavian clays, Hansbo [16] proposed that $\mathrm{s}_{\mathrm{u}}^{\mathrm{FV}} / \sigma^{\prime}{ }_{\mathrm{p}}$ is directly proportional to the liquid limit (LL). Bjerrum [17] reported that $s_{\mathrm{u}}^{\mathrm{FV}}$ must be transformed to mobilized undrained shear strength $\left(\mathrm{s}_{\mathrm{u}}(\mathrm{mob}) \approx \lambda \mathrm{s}_{\mathrm{u}}^{\mathrm{FV}}\right)$, where $\lambda$ is a correction multiplier that considers the rate effects as well as anisotropy. Mesri [18] provided a particular relationship for $s_{u}(\mathrm{mob})$ of clays and silts, which was practically analogous to the direct simple shear (DSS) test conditions, regardless of soil plasticity. However, as illustrated by Larsson [19], this relationship has a tendency to overestimate undrained shear strength in low-plasticity clays while underestimating it in high-plasticity clays.

Since then, a number of relationships have been developed based on the SHANSEP method [5]. Jamiolkowsky et al. [4] presented a correlation which describes the normalized $s_{u}$ with respect to the overconsolidation ratio. Larsson et al. [20] investigated the SHANSEP equation for Scandinavian inorganic soft clays. The undrained shear strength data, including those from DSS tests $\left(\mathrm{s}_{\mathrm{u}}^{\mathrm{DSS}}\right)$ were collected, it was demonstrated that normalized $\mathrm{s}_{\mathrm{u}}^{\mathrm{DSS}}$ with respect to the effective vertical stress $\left(\sigma_{\mathrm{v}}^{\prime}\right)$ depends on both overconsolidation ratio and liquid limit. Based on the 345 results on clays obtained from all over the world, Ching and Phoon [21] suggested a global model for $\mathrm{s}_{\mathrm{u}}(\mathrm{mob})$ derived from the field vane shear and unconfined compression tests with respect to OCR and sensitivity $\left(\mathrm{S}_{\mathrm{t}}\right)$. Based on laboratory experiments, Karlsrud and Hernandez-Martinez [22] examined the correlation between normalized undrained shear strength and overconsolidation ration for Norwegian soft clays. The results of their work showed that undrained shear strength from the DSS test are highly dependent on the natural water content $(w)$ associated with OCR. Table 1 summarizes the correlation of undrained shear strength with preconsolidation stress and overconsolidation ratio derived from various studies.

Table 1 Summary of literature correlations relating $s_{\mathbf{u}}$ with $\boldsymbol{\sigma}_{\mathbf{p}}^{\prime}$ and OCR

\begin{tabular}{cl}
\hline Expression & Reference \\
\hline $\mathrm{s}_{\mathrm{u}}^{\mathrm{FV}} / \sigma_{\mathrm{p}}^{\prime}=0.11+0.0037 \mathrm{PI}$ & Skempton [14] \\
$\mathrm{s}_{\mathrm{u}} / \sigma_{\mathrm{p}}^{\prime}=0.45 \mathrm{LL}$ & Hansbo [16] \\
$\mathrm{s}_{\mathrm{u}} / \sigma_{\mathrm{p}}^{\prime}=0.22$ & Mesri [18] \\
$\mathrm{s}_{\mathrm{u}}^{\mathrm{FV}} / \sigma_{\mathrm{p}}^{\prime}=0.08+0.0055 \mathrm{PI}$ & Larsson [19] \\
$\mathrm{s}_{\mathrm{u}} / \sigma_{\mathrm{p}}^{\prime}=0.23 \pm 0.04 \mathrm{OCR}^{0.8}$ & Jamiolkowsky [4] \\
$\mathrm{s}_{\mathrm{u}}^{\mathrm{DSS}} / \sigma_{\mathrm{v}}^{\prime}=\left(0.125+0.205 \mathrm{LL}^{\prime} 1.17\right) \mathrm{OCR}^{0.8}$ & Larsson et al [20] \\
$\mathrm{s}_{\mathrm{u}}(\mathrm{mob}) / \sigma_{\mathrm{v}}^{\prime}=0.229 \mathrm{~S}_{\mathrm{t}} \mathrm{OCR}^{0.823}$ & Ching and Phoon [21] \\
$\mathrm{s}_{\mathrm{u}}^{\mathrm{DSS}} / \sigma_{\mathrm{v}}^{\prime}=(0.14+0.18 \mathrm{w}) \mathrm{OCR}^{(0.35+0.77 \mathrm{w})}$ & Karlsrud and Hernandez-Martinez [22] \\
\hline
\end{tabular}

The determination of preconsolidation pressure using oedometer curves in certain cases, particularly in stiff to hard clays, is very difficult [23]. This paper suggests an alternative method based on the SHANSEP procedure 
which can be used to provide an independent assessment of $\sigma_{\mathrm{p}}^{\prime}$ in clays or supplement the consolidation test results. For this purpose, a series of direct shear tests under unconsolidated undrained conditions were conducted on samples made of clay and sand consolidated at different OCRs. The reliability of the SHANSEP method for estimating preconsolidation stress is investigated.

\section{SHANSEP PROCEDURE}

The approach of the normalized parameters was derived from the empirical observation that clay specimens with identical OCR but different consolidation stresses, and hence different preconsolidation pressures, present similar properties (undrained strength, shear induced pore pressures, etc.) when normalized against consolidation stress [24], these have conducted to the SHANSEP design procedure (Stress History and Normalized Soil Engineering Properties) developed by Ladd et al [5]. In addition, the concept of normalized parameters is considered crucial for other frameworks describing the behavior of soils such as Critical State Soil Mechanics [25], or analytical models such as Modified Cam Clay [26] and MIT-E3 [27]. The results can be illustrated by adopting the following expression, commonly termed as the SHANSEP equation:

$s_{u} / \sigma_{v}^{\prime}=S(O C R)^{m}$

Where:

$S=\left(s_{u} / \sigma_{v}^{\prime}\right)_{N C}$

$S$ is the normalized undrained shear strength at the normally consolidated state, and $m$ is an empirically determined factor governing the shape of the SHANSEP curve. Table 2 presents the values of SHANSEP parameters obtained from literature.

Table 2 Literature values of SHANSEP parameters $S$ and $m$

\begin{tabular}{|c|c|c|c|}
\hline \multicolumn{2}{|c|}{ SAHSNEP parameters } & \multirow{2}{*}{ Investigated soil } & \multirow{2}{*}{ Reference } \\
\hline$s$ & $m$ & & \\
\hline 0.20 & - & Sensitive marine clays & \multirow{4}{*}{ Ladd [28] } \\
\hline 0.22 & 0.80 & $\begin{array}{l}\text { Homogeneous clays of low to } \\
\text { moderate sensitivity }\end{array}$ & \\
\hline 0.16 & 0.75 & Northeastern US clays & \\
\hline 0.25 & 0.88 & $\begin{array}{l}\text { Sedimentary deposits of silts and } \\
\text { organic soils and clays with shells }\end{array}$ & \\
\hline 0.259 & 0.78 & Bukit Raja clay & Mohd Amin et al. [29] \\
\hline $0.245-0.27$ & $0.75-0.89$ & Bangkok clay & Seah and Lai [30] \\
\hline 0.25 & 0.76 & $\begin{array}{c}\text { Sensitive, soft and compressible } \\
\text { soil in Kolkata }\end{array}$ & Roy and Singh [31] \\
\hline $0.481-0.802$ & $0.118-0.256$ & Lower Silesia clay and silty clay & Stróżyk and Tankiewicz [32] \\
\hline
\end{tabular}

\section{MATERIALS AND METHODS}

\subsection{Identification of Materials}

The laboratory tests in this work were performed on a mixture of two materials. The first was a remodeled soil obtained from a large construction site in the region of Tlemcen, Algeria. It was classified according to the Unified Soil Classification System (USCS) as high-plasticity clay (CH). The second material was a natural sand obtained 
from the region of Bouihi, Algeria, and it was classified according to the USCS as poorly graded sand (SP). The materials were subjected to several laboratory tests using standard procedures in accordance with AFNOR standards [33-36]. Figure 1 presents the grain-size distribution curves of clay and sand. The properties of the materials are displayed in Table 3.

Table 3 Properties of materials

\begin{tabular}{|c|c|c|c|}
\hline \multicolumn{2}{|l|}{ Properties } & Clay & Sand \\
\hline \multicolumn{2}{|c|}{ Liquid limit, LL [\%] } & 54 & - \\
\hline \multicolumn{2}{|c|}{ Plastic limit, PL [\%] } & 21 & - \\
\hline \multicolumn{2}{|c|}{ Plasticity index, PI [\%] } & 33 & - \\
\hline \multicolumn{2}{|c|}{ Unit weight of solid particles, $\Upsilon_{\mathrm{s}}\left[\mathrm{kN} / \mathrm{m}^{3}\right]$} & 26.67 & 26.43 \\
\hline \multirow{3}{*}{ Particles size distribution } & $\% 2[\mathrm{~mm}]$ & 100 & 100 \\
\hline & $\% 80[\mu \mathrm{m}]$ & 92 & 1.54 \\
\hline & $\% 2[\mu \mathrm{m}]$ & 29 & - \\
\hline \multicolumn{2}{|c|}{ coefficient of uniformity, $C_{u}$} & - & 2.34 \\
\hline \multicolumn{2}{|c|}{ coefficient of curvature, $C_{c}$} & - & 0.96 \\
\hline
\end{tabular}

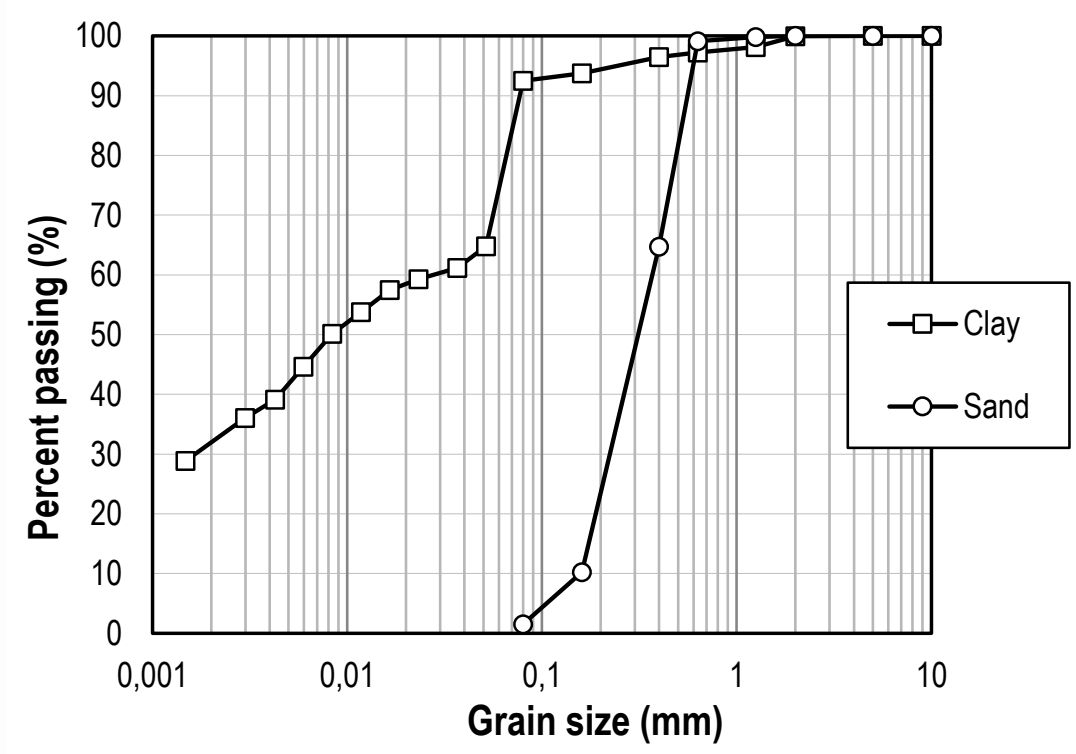

Figure 1 Particle size distribution curves of clay and sand

\subsection{Preparation of mixtures and samples}

This study was conducted on three mixtures, the first is totally made of clay (Mixture 1), the second containing 85 $\%$ clay and $15 \%$ sand (Mixture 2), and the third comprising $70 \%$ clay and $30 \%$ sand (Mixture 3 ). The samples should present the same characteristics (basically bulk density [37] and water content [38]) to avoid possible effects on the results at a later stage. Therefore, different samples were mixed with different amounts of water to determine the water content which ensures uniform initial parameters for all mixtures. Figures $2(A), 2(B)$, and 2 (C) represent the variation of dry unit weight $\left(\Upsilon_{\mathrm{d}}\right)$, initial void ratio $\left(e_{0}\right)$, and degree of saturation $\left(s_{r}\right)$ respectively, 
against the water content. According to these figures, the initial water content of $30 \%$ presents more or less the same density and offers a near saturation for all the mixtures, as shown in Table 4.
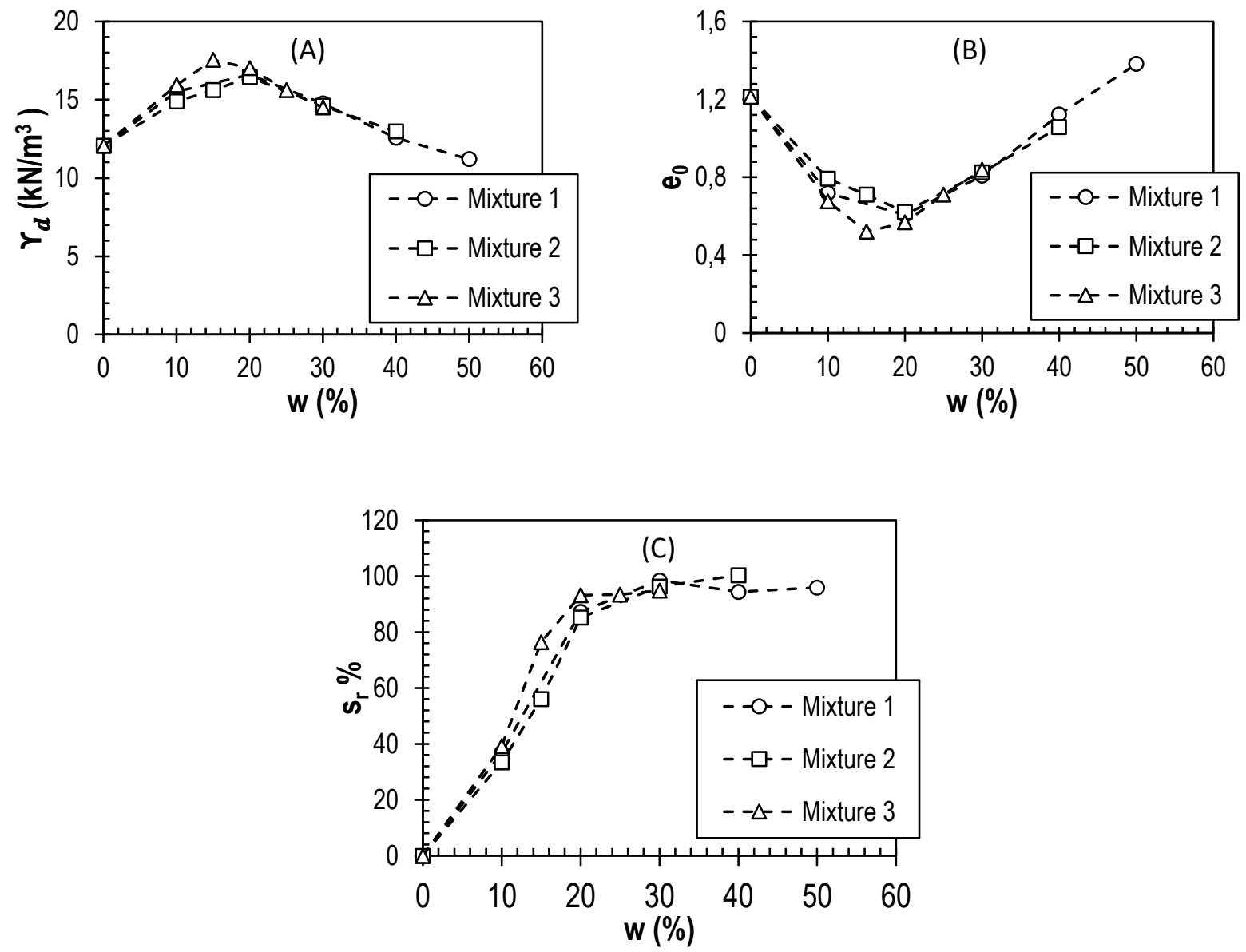

Figure 2 Variation of dry unit weight (A), initial void ratio (B) and degree of saturation (C) against the water content

Table 4 Mean characteristics of mixtures at $w=30 \%$

\begin{tabular}{cccc}
\hline & $\boldsymbol{\Upsilon}_{\mathbf{d}}\left[\mathrm{kN} / \mathrm{m}^{3}\right]$ & $\boldsymbol{e}_{\mathbf{0}}$ & $\boldsymbol{s}_{\boldsymbol{r}}[\%]$ \\
\hline Mixture 1 & 14.46 & 0.845 & 94.69 \\
Mixture 2 & 14.32 & 0.862 & 92.84 \\
Mixture 3 & 14.24 & 0.873 & 91.60 \\
\hline
\end{tabular}

\section{PROCEDURE AND APPLICATION OF THE SHANSEP METHOD}

Two series of tests were conducted: the first aimed at determining the SHANSEP parameters, and the second is dedicated to assess preconsolidation pressures. In this regard, the samples were mixed with an initial water content of $30 \%$, and then compacted in a mold of $60 \mathrm{~mm}$ diameter and $29 \mathrm{~mm}$ height (Figure 3) to achieve the set densities. Each mixture was subjected to the same stress path; the procedure involves the application of a preconsolidation pressure $\left(\sigma_{p}^{\prime}\right)$ to samples. The specimens are then allowed to swell one-dimensionally to a vertical effective stress $\left(\sigma_{\mathrm{v}}^{\prime}\right)$ at the desired OCR, as indicated in Table 5. 


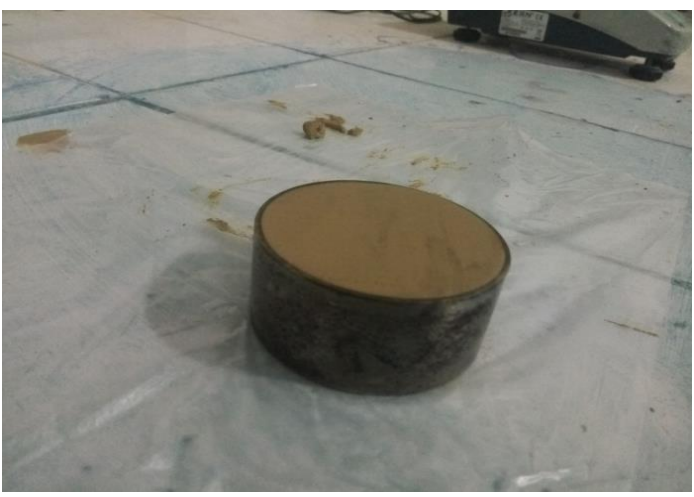

Figure 3 Compacted sample in the mold

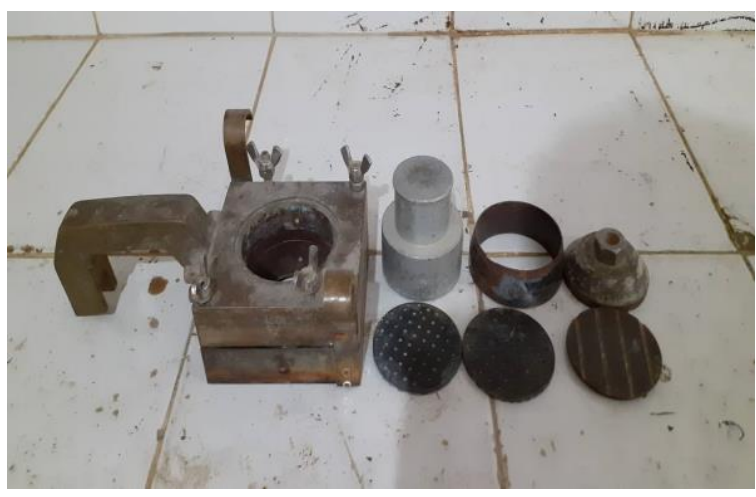

Figure 4 Disassembled shear box

For each OCR, three specimens each placed in the shear box (Figure 4) were subjected to various normal stresses $(100,200$, and $300 \mathrm{kPa})$, then sheared in direct shear apparatus, as shown in Figure 5, under unconsolidated undrained conditions at a constant speed of $1.5 \mathrm{~mm} / \mathrm{min}$. These same steps were repeated for all mixtures (Mixtures 1, 2, and 3).

\section{RESULTS AND INTERPRETATION}

\subsection{Determination of SHANSEP parameters}

Figure 6 illustrates the evolution of normalized undrained shear strength versus the overconsolidation ratio. SHANSEP equations (3), (4), and (5) corresponding respectively to each of the curves of Mixtures 1, 2, and 3 are given as follows:

$s_{u} / \sigma^{\prime}{ }_{v}=0.4156(O C R)^{0.1834}$, with $R^{2}=0.95$

$s_{u} / \sigma^{\prime}{ }_{v}=0.3160(O C R)^{0.2505}$, with $R^{2}=0.97$

$s_{u} / \sigma^{\prime}{ }_{v}=0.1951(O C R)^{0.3459}$, with $R^{2}=0.95$

Table 5 Applied stress path to the samples

\begin{tabular}{ccc}
\hline OCR & $\boldsymbol{\sigma}_{\mathbf{p}}^{\prime}[\mathrm{kPa}]$ & $\boldsymbol{\sigma}_{\mathbf{v}}^{\prime}[\mathrm{kPa}]$ \\
\hline \multicolumn{3}{c}{ First testing series } \\
2 & 45 & 45 \\
4 & 160 & 80 \\
8 & 400 & 100 \\
10 & 960 & 120 \\
\multicolumn{3}{c}{ Second testing series } \\
\hline 1.5 & 90 & 140 \\
3 & 270 & 60 \\
6 & 660 & 90 \\
7.5 & 975 & 110 \\
\hline
\end{tabular}

Chalabi, Y, Reiffsteck, P, Zadjaoui, A 


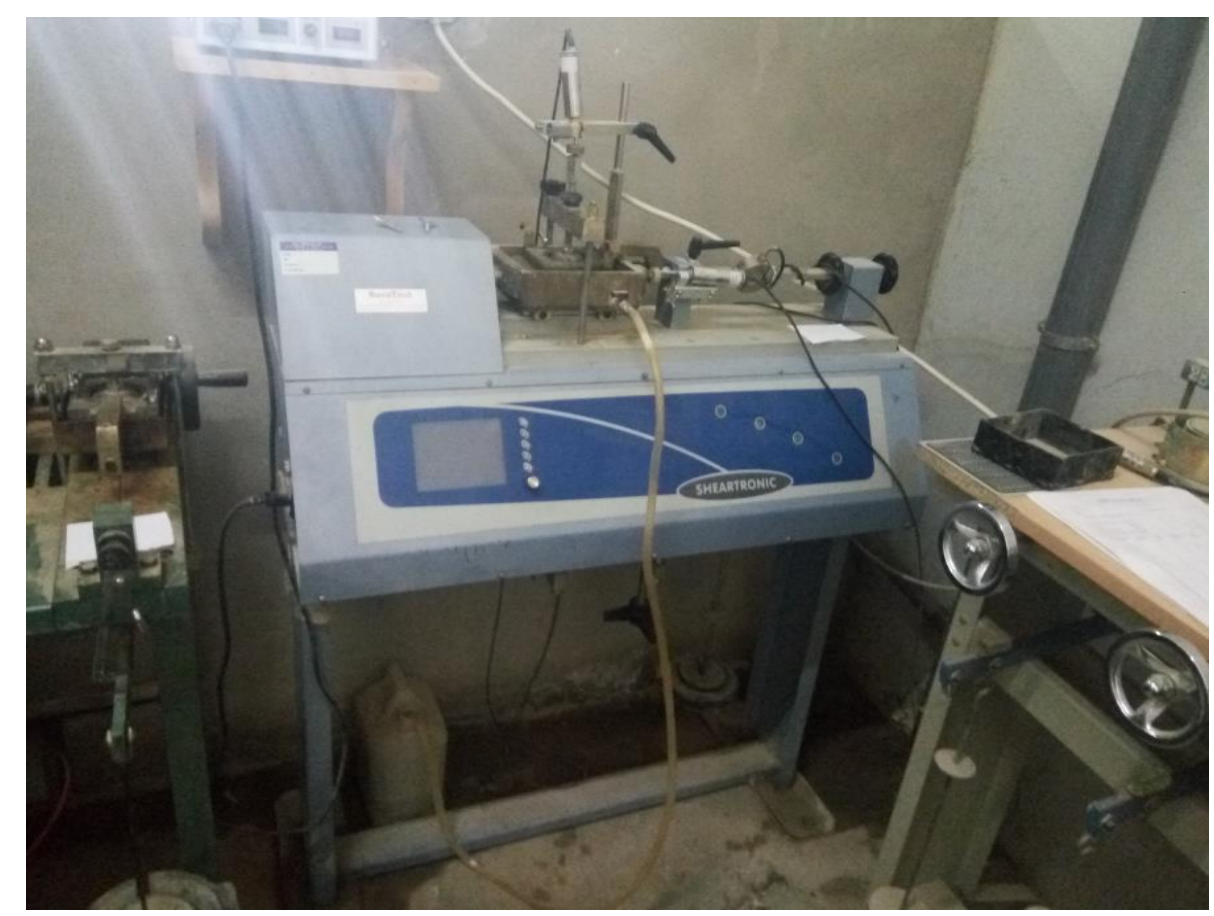

Figure 5 Direct-shear test apparatus

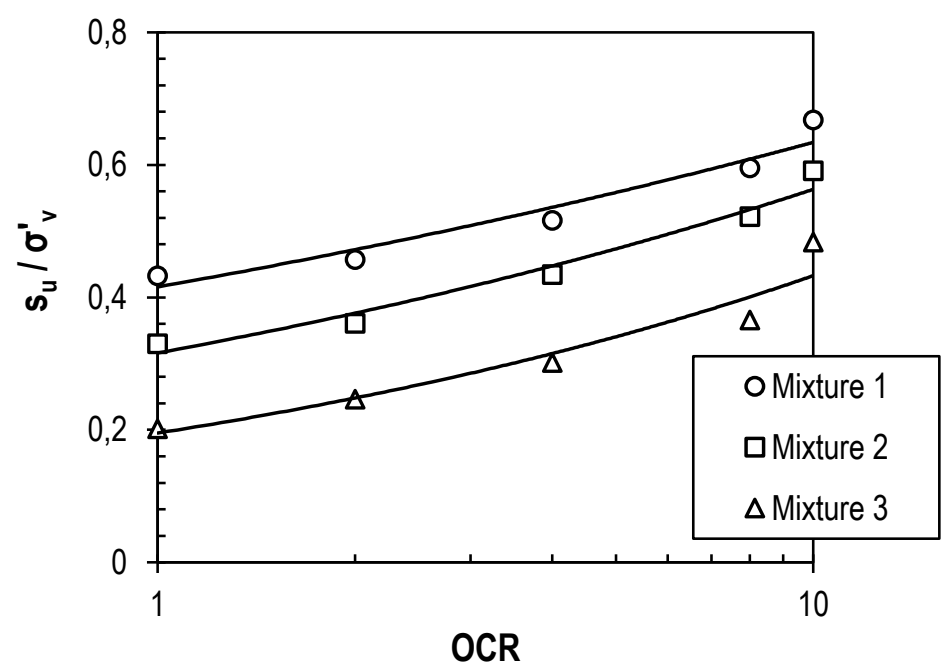

Figure 6 Evolution of normalized undrained shear strength as a function of overconsolidation ratio

The values of the undrained shear strength decrease with increase in the quantity of sand for all mixtures, as presented in Figure 7 (A). Furthermore, Figure 7 (B) shows that a higher sand content is reflected by an increase of parameter $m$ and a decrease of parameter $S$ in SHANSEP equation.

The non-null $m$ parameters identified for each of the mixtures denote a nonlinear relationship between $s_{u}$ and OCR. 

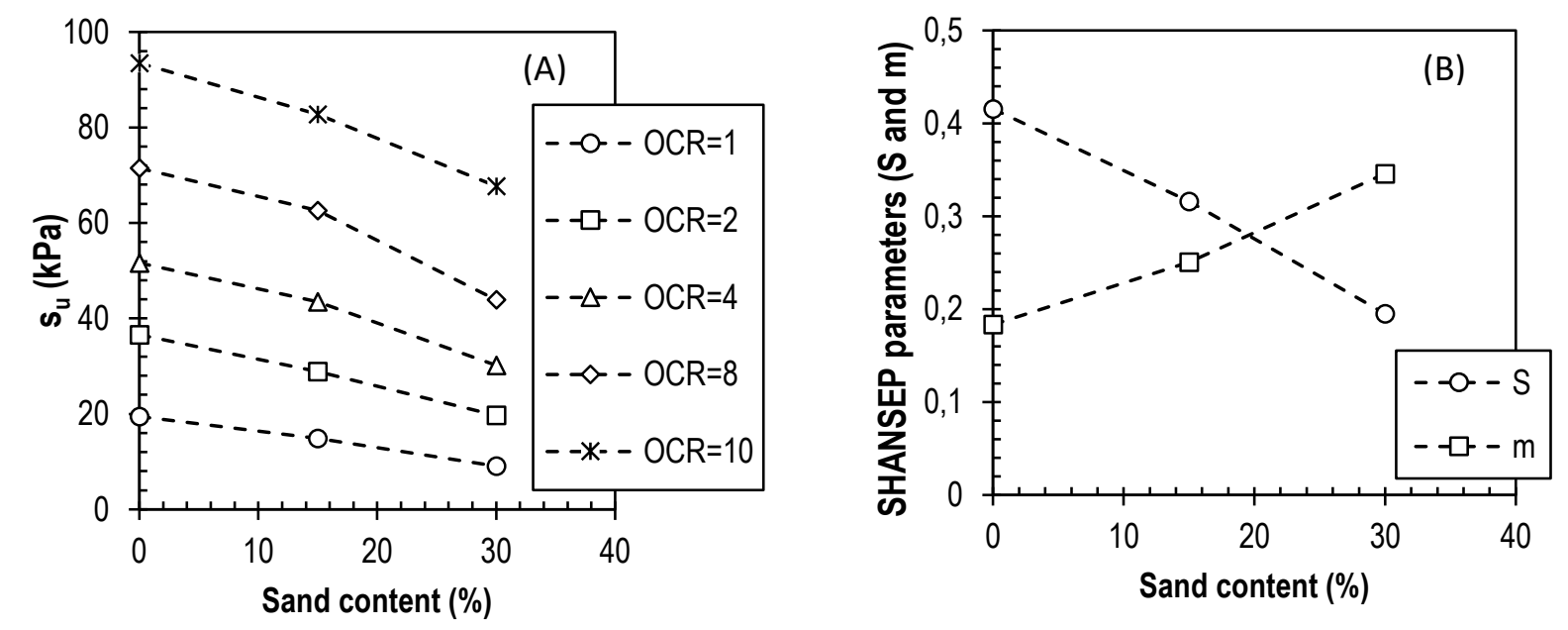

Figure 7 Influence of sand content on (A) undrained shear strength for different OCRs and (B) SHANSEP parameters ( $\mathrm{S}$ and $\mathrm{m})$

\subsection{Assessment of preconsolidation pressure}

The evolution of the undrained shear strength against OCR for the second series of tests is shown in Figure 8. SHANSEP equation (1) can be expressed as:

$O C R=\left[s_{u} / S \sigma_{v}^{\prime}\right]^{1 / m}$

and therefore,

$\sigma_{p}^{\prime}=\sigma_{v}^{\prime}\left[s_{u} / S \sigma_{v}^{\prime}\right]^{1 / m}$

Equation (7) includes two parameters already identified in the first experimental series ( $S$ and $m$ ) along with two variables $\left(s_{u}\right.$ and $\left.\sigma_{v}^{\prime}\right)$ resulting from the second set of tests. This equation is used to evaluate the preconsolidation pressures. A comparison between $\sigma_{p}^{\prime}$ estimated by equation (7) and $\sigma_{p}^{\prime}$ applied to samples described in the second test series (see Table 5 and Figure 9) illustrates that for a given OCR, the SHANSEP method predicts practically identical $\sigma_{p}^{\prime}$ values for all mixtures. The same figure shows an underestimation of the evaluated $\sigma_{p}^{\prime}$ values. Figure 10 indicates that the error related to the prediction of $\sigma_{p}^{\prime}$ increases with OCR. In addition, as the SHANSEP method is based on $\mathrm{s}_{\mathrm{u}}$ values, the reliability of $\mathrm{s}_{\mathrm{u}}$ derived from direct shear test in this study depends on OCR. In other words, the reliability of $\sigma_{p}^{\prime}$ assessed by the SHANSEP approach depends on the soil consolidation state. 


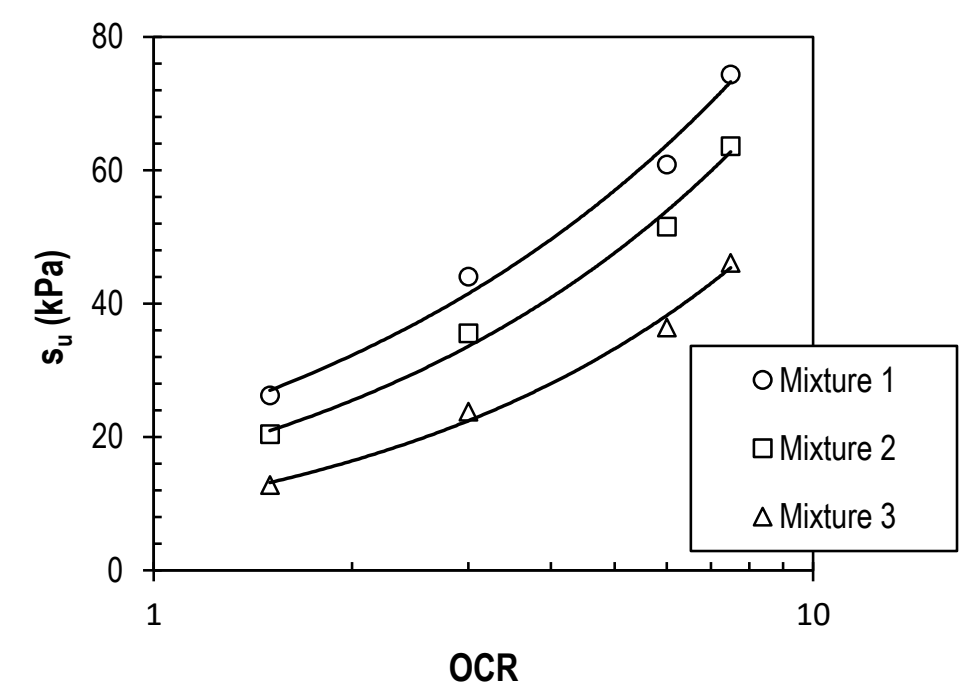

Figure 8 Evolution of undrained shear strength against OCR

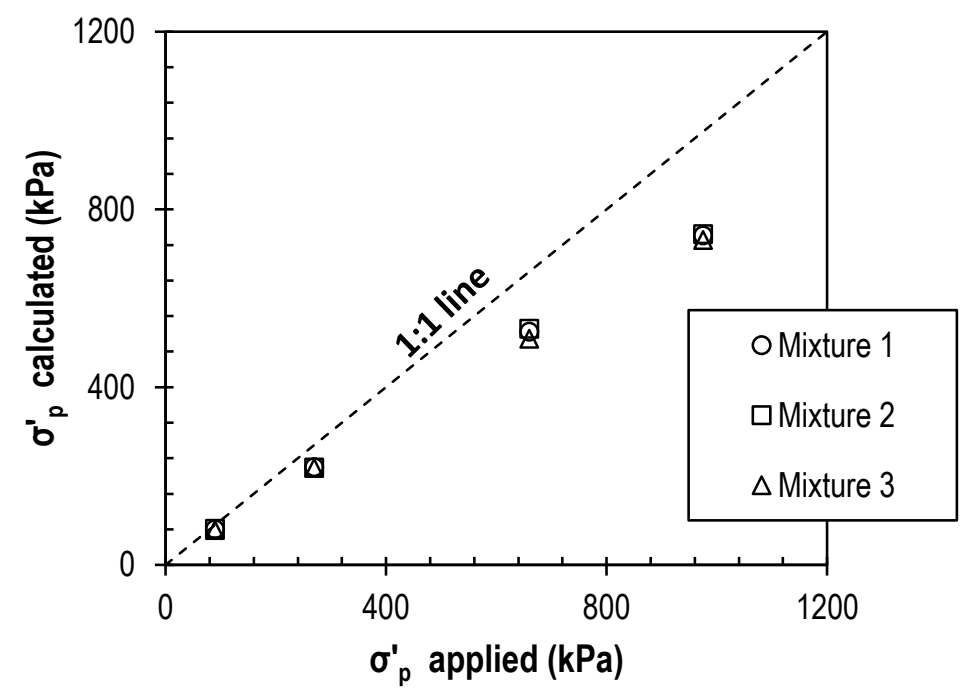

Figure 9 Comparison between calculated and applied values of $\sigma_{p}^{\prime}$ for the three mixtures 


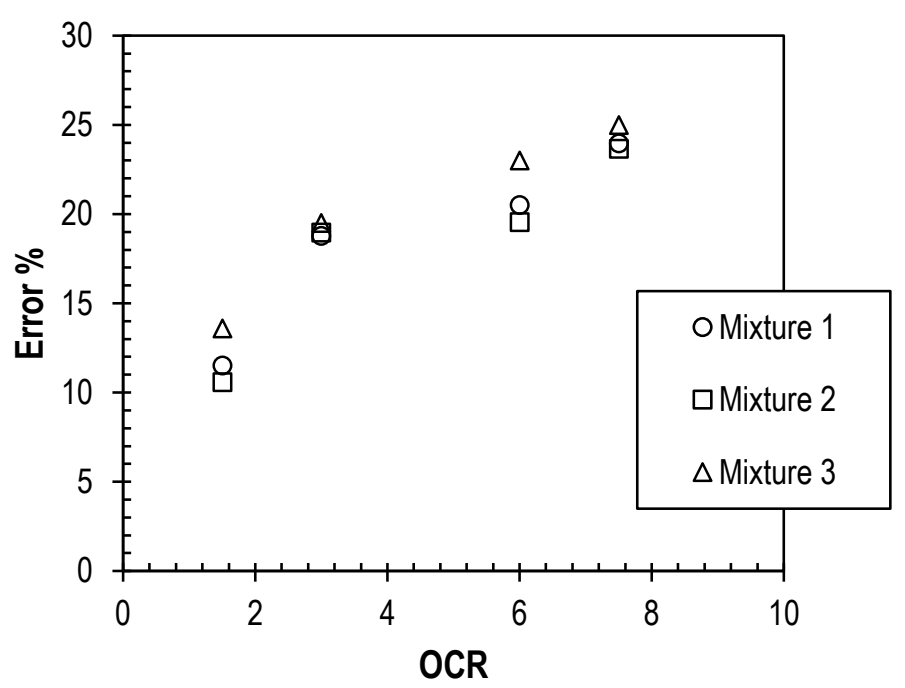

Figure 10 Error related to the prediction of $\sigma_{p}^{\prime}$ with respect to the overconsolidation ratio

\section{CONCLUSIONS}

This paper presented a study of the reliability of the SHANSEP method for assessing the preconsolidation stress. Several research projects conducted using this method generally considered clayey soils. The necessity to investigate this approach for soils with a texture different from that of clay can be of great practical utility. Therefore, two series of direct shear tests under unconsolidated undrained conditions were carried out on three mixtures with various proportions of clay and sand. The following conclusions can be drawn from the obtained results:

- A nonlinear relationship was observed between normalized undrained shear strength and the overconsolidation ratio.

- The SHANSEP parameters ( $S$ and $m$ ) are affected by the sand content in the mixtures, where the amount of sand is directly proportional to parameter $m$ and inversely proportional to parameter $S$.

- The reliability of undrained shear strength resulting from a direct shear test is dependent upon OCR.

In this work, the sand content had no effect on the evaluation of $\sigma_{p}^{\prime}$ when using the SHANSEP procedure. However, the reliability of the SHANSEP method for assessing the preconsolidation pressures was observed to depend on the soil consolidation state. Additional studies are required to understand the impact of soil particle size on the SHANSEP parameters.

\section{Acknowledgment}

The experimental results in this study were conducted in Lab-Analyse Engineering (Lae) and Laboratoire des Travaux Publics de I'Ouest (LTPO) in the province of Tlemcen, Algeria. The authors gratefully acknowledge the support provided for this work.

\section{References}

[1] Becker D.; Crooks J.; Been K.; Jefferies M. 1987: Work as a criterion for determining in situ and yield stresses in clays, Canadian Geotechnical Journal, 24 (4), pp. 549-564. https://doi.org/10.1139/t87-070

[2] Burland J. 1990: On the compressibility and shear strength of natural clays, Géotechnique, 40 (3), pp. 329378, https://doi.org/10.1680/geot.1990.40.3.329

Chalabi, Y, Reiffsteck, P, Zadjaoui, A 
[3] Casagrande A. 1936: The determination of pre-consolidation load and it's practical significance, Proceedings of the 1st International Conference on Soil Mechanics and Foundation Engineering, Cambridge, UK, 3, pp. 60-64.

[4] Jamiolkowsky M.; Ladd C.; Germaine J.; Lancellotta R. 1985: New developments in field and laboratory testing, in Proceedings of the Eleventh International Conference on Soil Mechanics and Foundation Engineering, San Francisco, pp. 57-153.

[5] Ladd C.; Foott R. 1974: New design procedure for stability of soft clays, Journal of the Geotechnical Engineering Division, 100, pp. 763-786.

[6] Mesri G.; Godlewski P.M. 1977: Time-and stress-compressibility interrelationship, Journal of the Geotechnical Engineering Division, 103, pp. 417-430.

[7] Wroth C. 1984: Interpretation of in situ soil tests, Geotechnique, 34 (4), pp. 449-489. https://doi.org/10.1680/geot.1984.34.4.449

[8] Boone S.J. 2010: A critical reappraisal of "preconsolidation pressure" interpretations using the oedometer test, Canadian Geotechnical Journal, 47 (3), pp. 281-296. https://doi.org/10.1139/t09-093

[9] Jose B.T.; Sridharan A.; Abraham B. 1989: Log-log method for determination of preconsolidation pressure, Geotechnical Testing Journal, 12 (3), pp. 230-237. https://doi.org/10.1520/gtj10974j

[10] Wang L.; Frost J. 2004: Dissipated strain energy method for determining preconsolidation pressure, Canadian Geotechnical Journal, 41 (4), pp. 760-768. https://doi.org/10.1139/t04-013

[11] Larsson R.; Åhnberg H. 2005: On the evaluation of undrained shear strength and preconsolidation pressure from common field tests in clay, Canadian Geotechnical Journal, 42 (4), pp. 1221-1231, https://doi.org/10.1139/t05-031

[12] Mayne P.W.; Kemper J. 1988: Profiling OCR in stiff clays by CPT and SPT, Geotechnical Testing Journal, 11 (2), pp. 139-147, https://doi.org/10.1520/GTJ10960J

[13] Singh V.; Chung S. 2015: Evaluation of overconsolidation ratios from laboratory and in situ tests on Busan clay, Engineering Geology, 199, pp. 38-47. https://doi.org/10.1016/i.enggeo.2015.10.006

[14] Skempton A. 1954: Discussion of the structure of inorganic soil, Journal of American Society of Civil Engineers, 80 (478), pp. 19-22.

[15] Chandler R.J. 1988: The in-situ measurement of the undrained shear strength of clays using the field vane, Vane shear strength testing in soils: field and laboratory studies, pp. 13-45. https://doi.org/10.1520/stp10319s

[16] Hansbo S. 1957: A new approach to the determination of the shear strength of clay by the fall-cone test, Royal Swedish Geotechnical Institute, Stockholm Proceedings No. 14.

[17] Bjerrum L. 1972: Embankments on soft ground, performance of earth and earth-supported structures, in Proc. ASCE Specialty Conf, 2, pp. 1-54.

[18] Mesri G. 1975: New design procedure for stability of soft clays, in Journal of Geotechnical and Geoenvironmental Engineering, vol. 101, N GT4, pp. 409-412.

[19] Larsson R. 1980: Undrained shear strength in stability calculation of embankments and foundations on soft clays, Canadian Geotechnical Journal, 17 (4), pp. 591-602. https://doi.org/10.1139/t80-066

[20] Larsson R.; Sällfors G.; Bengtsson P.; Alén C.; Bergdahl U.; Eriksson L. 2007: Information 3, Skjuvhållfasthet-utvärdering i kohesionsjord, ed: Linköping: Swedish Geotechnical Institute.

[21] Ching J.; Phoon K-K. 2012: Modeling parameters of structured clays as a multivariate normal distribution, Canadian Geotechnical Journal, 49 (5), pp. 522-545. https://doi.org/10.1139/t2012-015

[22] Karlsrud K.; Hernandez-Martinez F.G. 2013: Strength and deformation properties of Norwegian clays from laboratory tests on high-quality block samples, Canadian Geotechnical Journal, 5 (12), pp. 1273-1293. https://doi.org/10.1139/cgj-2013-0298

[23] Mayne P.W. 1988: Determining OCR in clays from laboratory strength, Journal of Geotechnical Engineering, 114 (1), pp. 76-92. https://doi.org/10.1061/(ASCE)0733-9410(1988)114:1(76)

[24] Casey B.A. 2014: The consolidation and strength behavior of mechanically compressed fine-grained sediments, PhD thesis, Massachusetts Institute of Technology, USA.

[25] Schofield A.; Wroth P. 1968: Critical state soil mechanics, McGraw-Hill, London.

[26] Roscoe K.H.; Burland J. 1968: On the generalized stress-strain behaviour of wet clay, in Engineering Plasticity, pp. 535-609. 
[27] Whittle A.J.; Kavvadas M.J. 1994: Formulation of MIT-E3 constitutive model for overconsolidated clays, Journal of Geotechnical Engineering, 120 (1), pp. 173-198. https://doi.org/10.1061/(ASCE)07339410(1994)120:1(173)

[28] Ladd, C. C. 1991: Stability Evaluation during Staged Construction, Journal of Geotechnical Engineering, 117 (4), pp. 540-615. https://doi.org/10.1061/(ASCE)0733-9410(1991)117:4(540)

[29] Mohd Amin, J.; Taha, M. R.; Ahmed, J.; Kassim, A. A.; Jamaluddin, A.; Jaadil, J. 1997: Prediction and determination of undrained shear strength of soft clay at Bukit Raja. Pertanika Journal of Science \& Technology, 5 (1), pp. 111-126.

[30] Seah, T. H.; Lai, K. C. 2003: Strength and deformation behavior of soft Bangkok clay, Geotechnical Testing Journal, 26 (4), pp. 421-431. https://doi.org/10.1520/GTJ11260J

[31] Roy, D.; Singh, R. 2008: Mechanically Stabilized Earth Wall Failure at Two Soft and Sensitive Soil Sites, Journal of Performance of Constructed Facilities, 22 (6), pp. 373-380. https://doi.org/10.1061/(ASCE)08873828(2008)22:6(373)

[32] Stróżyk, J.; \& Tankiewicz, M. 2014: The Undrained Shear Strength of Overconsolidated Clays, Procedia Engineering, 91, pp. 317-321. https://doi.org/10.1016/j.proeng.2014.12.067

[33] AFNOR, NF P94-051. 1993: Détermination des limites d'Atterberg - Limite de liquidité à la coupelle - Limite de plasticité au rouleau. Sols: reconnaissance et essais.

[34] AFNOR, NF P94-054. 1991: Détermination de la masse volumique de particules solides des sols - Méthode du pycnomètre à eau. Sols: reconnaissance et essais.

[35] AFNOR, NF P94-056. 1996: Analyse granulométrique - Méthode par tamisage à sec après lavage. Sols: reconnaissance et essais.

[36] AFNOR, NF P94-057. 1992: Analyse granulométrique des sols - Méthode par sédimentation. Sols: reconnaissance et essais.

[37] AFNOR, NF P94-053. 1991: Détermination de la masse volumique des sols fins en laboratoire - Méthodes de la trousse coupante, du moule et de l'immersion dans l'eau. Sols: reconnaissance et essais.

[38] AFNOR, NF P94-050. 1995: Détermination de la teneur en eau pondérale des matériaux - Méthode par étuvage. Sols: reconnaissance et essais.

Please cite this article as: Chalabi, Y.; Reiffsteck, P.; Zadjaoui, A.: Applicability of SHANSEP method in evaluation of preconsolidation pressure, Electronic Journal of the Faculty of Civil Engineering Osijek-e-GFOS, 2020, 20, pp. 13-24, https://doi.org/10.13167/2020.20.2 